\title{
ECOLOGICAL SERVICES OF GREEN AREAS IN THE MAIN SQUARE OF KECSKEMÉT
}

\author{
Tímea Kiss $^{1^{*}}$, Károly Ecseri ${ }^{1}$ and Edit Hoyk ${ }^{2}$ \\ ${ }^{1}$ Department of Horticulture, Faculty of Horticulture and Rural Development, John von Neumann University, \\ Hungary \\ ${ }^{2}$ Department of Agricultural Economics and Rural Development, Faculty of Horticulture and Rural \\ Development, John von Neumann University, Hungary \\ https://doi.org/10.47833/2020.2.AGR.033
}

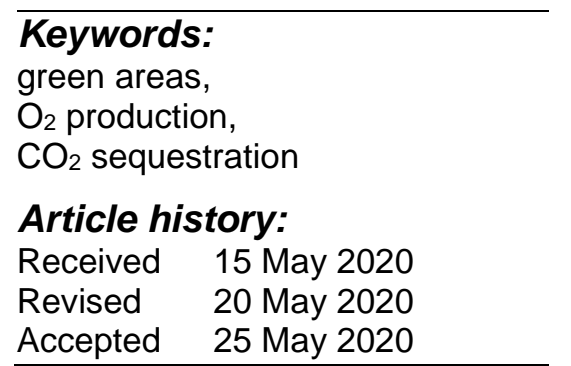

\begin{abstract}
Nowadays, as more and more people work to protect and preserve our environment, the importance of trees and tree plantings is also coming to the fore. The environmental benefits of trees are obvious, as they have a positive effect on the microclimate of a given area, be it a park, a public area covered with trees or a road lined with trees. Their important role in filtering out contaminants and dust can not be neglected.
\end{abstract}

\section{Introduction}

During the research, the woody plants of Kecskemét were examined in the main square of our city. Kecskemét has retained its market town character, but the proportion of its green areas continues to decrease significantly. Therefore, it is important to examine and prove with data the importance of nearly 250 trees in the study area in improving the city's climate: how much $\mathrm{CO} 2$ is bound, how much $\mathrm{O} 2$ contributes to the city's air, how much dust can be covered by foliage and how long these plants evaporate. Nothing proves the importance of trees better than the data that a dormant adult consumes $2.6-3.5 \mathrm{~kg}$ of oxygen per day, i.e. a 20-meter deciduous tree is about. It covers the daily oxygen needs of 100 people.

It is well known that the role of green space, i.e. the totality of vegetated areas, is decisive in the ecosystem. The impact of vegetation on the urban environment is multifaceted, it fulfills several functions at the same time, such as: ecological, functional, settlement structure and aesthetic role. As a biologically active surface, green space has a significant conditioning effect on its environment: it has a positive effect on climate, air quality, water management conditions, surface and groundwater quality, and prevents soil quantitative and qualitative degradation [7]. The species and varieties planted in cities today have not only aesthetic and sentimental value, but also make a significant contribution to maintaining a livable human environment. [11]; [12]; [6].

One cubic meter of assimilating surface produces 650 grams of oxygen and 590 grams of carbon dioxide during a growing season. In fact, this is called the environmental utility value. Of course, this value depends on many factors, such as site conditions, climatic factors, age of the tree, viability and health, species, variety, shape, surface, diameter of the crown. The environmental usefulness of a given tree is determined by its foliage volume, the photosynthetic surface, as the foliage surface is involved in $\mathrm{CO}_{2}$ sequestration, $\mathrm{O}_{2}$ production, humidification, dust binding, noise reduction [11]. However, in an urban application environment, we have limited information on the environmental benefits of planted tree species $\left(\mathrm{CO}_{2}\right.$ sequestration, evaporation), and few scientific sources can be found on the subject [4]. Assessing the environmental benefits of urban trees requires in situ measurements, but these measurements and data are almost completely missing. The characterization of these relationships and the knowledge of the data provide an opportunity to plan urban afforestation [5].

\footnotetext{
* Corresponding author. Tel.: +36 76517655

E-mail address: kiss.timea@kvk.uni-neumann.hu
} 


\subsection{Binding of pollutants}

Tree planting (also known as "greening") is proposed as one method to reduce airborne dust in urban areas, as trees are an effective complement to air pollution reduction [3]. The foliage acts as a biofilter for air pollution and improves air quality due to the coarse texture of the leaves and the large contact area. Green belts with vegetation (i.e., areas of natural or planted herbaceous and nonherbaceous plants) can effectively reduce dust and filter out suspended particles [9]. Some of the air pollutants can be captured by the foliage of trees. The filter works so that solid contaminants (dust particles with adhering heavy metals, soot, oil derivatives, asbestos, etc.) settle on the leaves. Rainwater washes away dirt from time to time and the filter leaf surface is operational again. According to research, 1 cubic meter of leaf area can remove 4,500 grams of pollutants from the air during a growing season [10].

\subsection{Determining the usefulness of woody plants}

1. Crown sizes:

The crown of a tree - from a forest estimation point of view - is the totality of living branches.

Dimensions of the crown from the point of view of forest estimation:

- crown diameter, crown projection;

- height of the crown;

- the crown projection;

- crown volume.

2. Crown diameter, crown projection:

The shape and size of the crown projection depends on the tree species, age, distance between trees, and, of course, environmental factors. In the vast majority of cases, the typical crown shape can only be used in the case of free-standing trees. Measuring the diameter of the crown in two directions can lead to a very inaccurate result. More accurate than this method is the measurement of multiple radial directions (at the characteristic breaking points of the crown projection) [4] is the "spoke" method. The average crown diameter can be calculated as the average of four canopy radii.

3. Crown height, crown volume:

Altimeters can generally be divided into two groups. The first includes those which use is based on the principle of similar triangles, and the second includes those that determine height by trigonometric means [16]. A simple way to measure trees is with the measuring rod method. Using this method, using altitude geometry, we calculate the height based on the principle of similar triangles, as shown in Figure 1 [8]. The figure shows that $h$ is related to $\mathrm{s}$ as $\mathrm{H}$ is to $\mathrm{S}$. Height can be easily expressed from this ratio:

$$
H=\frac{h}{S} \times S
$$

That is, knowing these three data $(h, s, S)$, the height of the tree $(H)$ can be calculated [16].

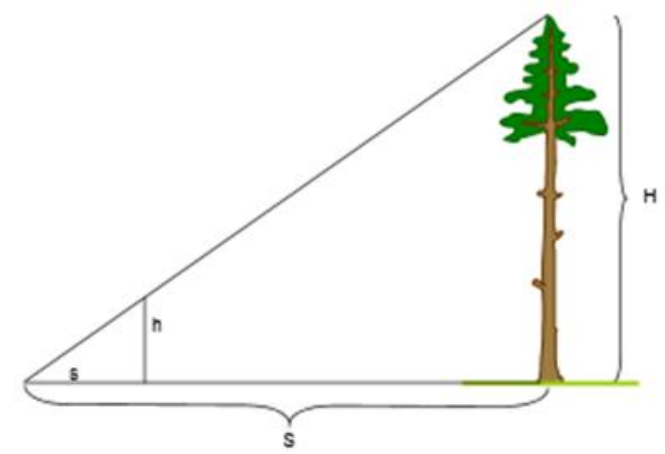

Figure 1: Schematic drawing of tree height calculation [16] 


\section{Material and method}

\subsection{Measurements}

In the first step, we determined the species and, if necessary, the variety of the woody plant. During the survey, each plant was given a unique identifier: an abbreviation of a scientific name and a serial number obtained during the survey. (Ex.: CO04 - Celtis occidentalis 4th in order). A total of 243 plants and 45 taxa were recorded. Species were determined based on Tóth [14]. The work of Schmidt and Tóth [12] was used as a basis for determining the shape of the canopy.

During the work we determined the height of the trees (using the method of equal triangles), within this we also measured the height of the trunks. To determine the volume, it was also necessary to calculate the area of the canopy projection. To do this, the radius of the crown was measured in four directions and then this area was averaged. For shrubs and shrub patches (e.g., Pyracantha coccinea) volume was determined by multiplying average width, length and height.

A measuring rod and a measuring tape were used for the measurement. From the available data, we calculated the canopy height of the trees. We also calculated canopy volume, which was calculated with different multipliers per crown form based on the work of Coder [2].

Knowing the value of the crown volume, we were able to calculate the value of environmental utility. This data shows the biologically active surface and value of the examined woody plants included in the survey. The examined data are crown volume $\left(\mathrm{m}^{3}\right)$, amount of $\mathrm{O}_{2}$ and bound $\mathrm{CO}_{2}$ produced during the vegetation period $(\mathrm{kg})$, dust retention $(\mathrm{kg})$ and evaporation (l). These data are a good illustration of the environmental utility of woody plants, which is determined by the surface area and volume of the crown.

The obtained results were categorized according to the crown volume of the plants.

\section{Results}

\section{Environmental utility of plants with a leaf volume of less than $2.5 \mathrm{~m}^{3}$}

There are 31 individuals in this category. The surveyed Ilex aquifolium plants have a very low foliage, some of the fig trees (Morus alba 'Pendula') and freshly planted; a few years old specimens. The total foliage volume is $28.1 \mathrm{~m}^{3}$ with an environmental utility of $16.6 \mathrm{~kg} \mathrm{CO}_{2}$; and $126.4 \mathrm{~kg}$ of pollutant sequestration, $18.3 \mathrm{~kg}$ of $\mathrm{O}_{2}$ emissions and $1.31 \mathrm{~m}^{3}$ of water evaporation into the atmosphere during a growing season.

\section{Environmental utility of plants with a leaf volume between 2.5 and $10 \mathrm{~m}^{3}$}

Observing 37 individuals within the group, it can be concluded that a significant proportion of Liriodendron tulipifera specimens fall into this category. In addition, Picea pungens and Tilia tomentosa trees dominate this size range in the vast majority. The total amount of gases used during assimilation is already significant $\left(110.9 \mathrm{~kg} \mathrm{CO}\right.$ and $\left.122.2 \mathrm{~kg} \mathrm{O}_{2}\right)$, and their role in the purification of the air in the Main Square is also noteworthy (845.8 kg pollutant sequestration). These woody ornamentals contribute to the reduction of atmospheric drought by evaporating $8.8 \mathrm{~m}^{3}$ of water.

3. Environmental utility of plants with a leaf volume between 10 and $20 \mathrm{~m}^{3}$

Significant diversity can be observed for the 21 individuals included here. This category also includes coniferous (Taxus baccata), scale leaved (Juniperus virginiana 'Grey Owl') and broad leaved evergreen (Ilex auifolium, Viburnum rhytidophyllum) in addition to deciduous species. The level of ecological services is similar to the data calculated for the previous group $(176.4 \mathrm{~kg} \mathrm{CO} 2$ capture, $194.3 \mathrm{~kg} \mathrm{O}_{2}$ emissions, $1345.2 \mathrm{~kg}$ pollutant capture, $14.1 \mathrm{~m}^{3}$ water evaporation).

4. Environmental utility of plants with a leaf volume between 20 and $50 \mathrm{~m}^{3}$

In this case, 41 plants were grouped. The number of individuals of the Celtis occidentalis species dominant in the whole area is significant (9), and Corylus colurna represents a higher value (7). Among the tall trees (plant height around 20 meters) there are also 3 individuals (2 Metasequoia glyptostroboides and 1 Populus nigra 'Italica'). The environmental utility data for the entire group are as follows: $833.8 \mathrm{~kg} \mathrm{CO}_{2}$ sequestration, $918.6 \mathrm{~kg} \mathrm{O}_{2}$ emissions, $6359.5 \mathrm{~kg}$ pollutant sequestration, and $66.4 \mathrm{~m}^{3}$ water evaporation.

5. Environmental utility of plants with a foliage volume between 500 and $1000 \mathrm{~m}^{3}$

Exactly half (21) of the 42 individuals in this category are members of the Celtis occidentalis genus. In addition, Morus alba 'Macrophylla' and Styphnolobium japonicum specimens are found in 
even greater numbers in this group. With the exception of a few lower-sized common hackberry and mulberries, these taxa already have plant heights greater than 10 meters. The atmosphere is enriched with $1986.5 \mathrm{~kg}$ of $\mathrm{O}_{2}$, and these dendrotaxones sequester more than 1.8 tons $(1803.2 \mathrm{~kg})$ of $\mathrm{CO}_{2}$. Their environmental benefits are also reflected in the capture of $13,752.9 \mathrm{~kg}$ of pollutants and the evaporation of $143.6 \mathrm{~m}^{3}$ of water.

6. Environmental utility of plants with a leaf volume between 100 and $150 \mathrm{~m}^{3}$

Celtis occidentalis individuals (12 of the 24 plants) also make up $50 \%$ of this group. The number of Styphnolobium japonicum individuals (7) is also dominant. The extent of ecological services for these 24 plants is as follows: $1764.2 \mathrm{~kg} \mathrm{CO}_{2}$ sequestration, $1943.6 \mathrm{~kg} \mathrm{O}_{2}$ emissions, $13455.5 \mathrm{~kg}$ pollutant sequestration, and $140.5 \mathrm{~m}^{3}$ water vapor emissions.

7. Environmental utility of plants with a foliage volume between $150-200 \mathrm{~m}^{3}$

10 of the trees in this category are Celtis occidentalis. 3 of the Quercus robur species and 6 of the Styphnolobium japonicum plant form this size category. Total $\mathrm{CO}_{2}$ sequestration exceeds 2.2 tonnes $(2208.6 \mathrm{~kg})$ and $\mathrm{O}_{2}$ emissions exceed 2.4 tonnes $(2433.2 \mathrm{~kg})$. Of these harmful substances in the air, $16,844.9 \mathrm{~kg}$ are filtered out by these specimens, and $175.9 \mathrm{~m}^{3}$ of water is evaporated to cool their environment.

8. Environmental utility of plants with a leaf volume above $200 \mathrm{~m}^{3}$

There are 26 plants in this category. The number of Celtis occidentalis is also outstanding in this group. However, one Quercus robur tree $\left(495 \mathrm{~m}^{3}\right)$ has the highest foliage volume value of the entire studied stand. This individual has $292 \mathrm{~kg}$ of $\mathrm{CO}_{2}$ sequestration and $321.7 \mathrm{~kg}$ of $\mathrm{O}_{2}$ emissions. Of the contaminants, this single specimen binds $2227.3 \mathrm{~kg}$ and evaporates $23.3 \mathrm{~m}^{3}$ of water during one vegetation period.

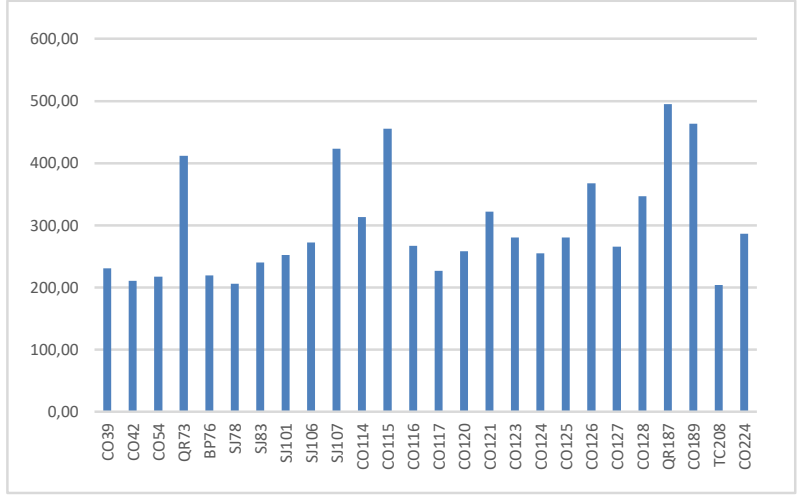

Figure 2: Distribution of trees with a leaf volume above than $200 \mathrm{~m}^{3}$

Examining the foliage volume data, it can be stated that the total value of this category is $7771.8 \mathrm{~m}^{3}$. This figure is $40 \%$ of the total stock. Exotic species with rapid initial growth belong mainly to this group (Celtis occidentalis, Styphnolobium japonicum). The age of these specimens is presumably 100-120 years (Figure 2). An individual plant of $200 \mathrm{~m}^{3}$ has an average leaf area of 800 $\mathrm{m}^{2}$, which is approximately equal to the area of a football field.

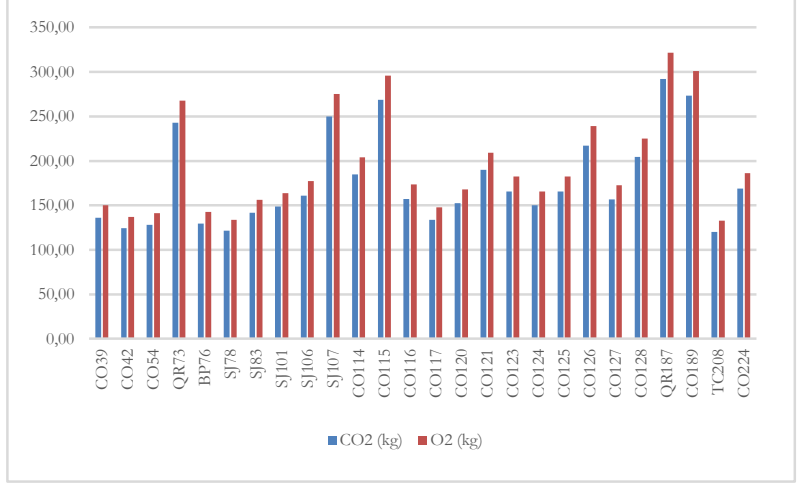

Figure 3: Oxygen production and carbon sequestration of trees with a leaf volume of more than $200 \mathrm{~m}^{3}$ 
In terms of environmental benefits, it is worth considering not only gas exchange during inhalation of humans, but also the amount of $\mathrm{O}_{2}$ used by motor vehicles and the amount of $\mathrm{CO}_{2}$ emitted were becoming more and more important in the 21th century. A car emits approximately 20 $27 \mathrm{~kg}$ of $\mathrm{CO}_{2}$ per $100 \mathrm{~km}$ [13]. The total $\mathrm{CO}_{2}$ sequestration $(4585.4 \mathrm{~kg})$ of the plant individuals shown in Figure 3 neutralizes the emissions of 1698-2293 cars.

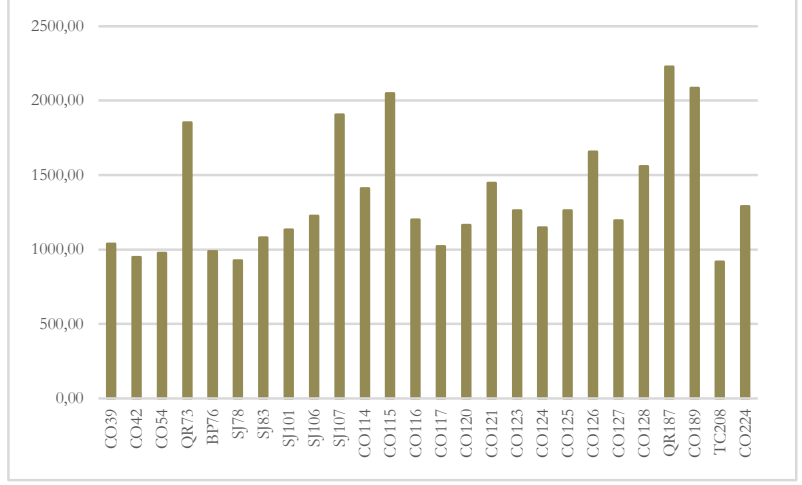

Figure 4: Pollutant absorption of trees with a leaf volume of more than $200 \mathrm{~m}^{3}$

The most significant pollutants are sulfur dioxide, oxidized nitrogen compounds $\left(\mathrm{NO}_{2}, \mathrm{NO}\right)$, carbon monoxide and flour. In addition, solid atmospheric components (dust, particles) should be mentioned, the most dangerous of which are fractions with a particle size of less than 10 and 2.5 $\mu \mathrm{m}$, respectively [1]. In the case of these particles, however, the binding capacity of the foliage can be taken into account not only once, but the biological filtering effect reappears after each precipitation. Due to this, the values shown in Figure 4 are an order of magnitude higher than the data calculated for atmospheric gases.

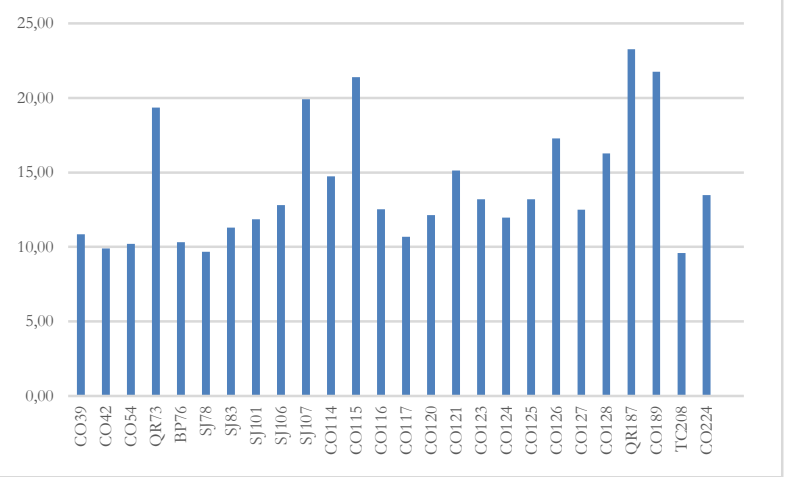

Figure 5: Water evaporation from trees with a leaf volume greater than $200 \mathrm{~m}^{3}$

The rate of evaporation in a tree-covered area can be up to 300-400 liters per square meter per year. This results in a significant increase in humidity (on average 5-6\%), and the energy removal capacity of such a large amount of water is considerable (732-919 thousand kJ), which can reduce the air temperature by $10-13^{\circ} \mathrm{C}[12]$.

\section{Conclusions}

The total assimilating surface of the surveyed stock is $19489.6 \mathrm{~m}^{3}$. The $\mathrm{CO}_{2}$ sequestration of these 243 plants is $11498.9 \mathrm{~kg}$ and the $\mathrm{O}_{2}$ emission is $12668.2 \mathrm{~kg}$. This (calculated on an average of $3 \mathrm{~kg}$ ) meets the daily oxygen needs of 4223 people. These dendrotaxones contribute to a healthier environment by absorpting $87703.2 \mathrm{~kg}$ of pollutant and evaporating $916 \mathrm{~m}^{3}$ of water. The average plant cover of the surveyed area $\left(38800 \mathrm{~m}^{2}\right)$ is 0.006 pieces $/ \mathrm{m}^{2}$ in the case of the examined dendrological stock. The area shaded by the surveyed tree-shrubs $\left(20,400 \mathrm{~m}^{2}\right)$ is $52.6 \%$ of the Main Square (excluding the overlaps of individuals adjacent to and above each other).

\section{Acknowledgment}


Thank you for the support of the research carried out in the framework of the EFOP-3.6.2-162017-00012 „Developing a functional, healthy and safe food product chain model from field to table in a thematic research network". The project is funded by the Hungarian State and the European Union, co-financed by the European Social Fund, and is part of the Széchenyi 2020 program.

\section{References}

[1] Barótfi István (2000): Környezettechnika. Mezőgazda Kiadó, Budapest p. 982

[2] Coder, Kim D. (2018): Drought, Heat \& Trees: - a learning manual. Warnell School of Forestry \& Natural Resources, University of Georgia p. 57.

[3] Escobedo, Francisco J.- David J. Nowak (2009): Spatial heterogeneity and air pollution removal by an urban forest. Landscape and Urban Planning 90 pp. 102-110.

[4] Forrai Mihály - Sütöriné Diószegi Magdolna -Juhász Ágota - Hrotkó Károly (2012): A kőris (excelsior 'Westhof's Glorie') leveleinek gázcseréje különböző alkalmazási környezetben. In: Fenntartható fejlődés, élhető régió, élhető települési táj 1. Budapesti Corvinus Egyetem, Budapest, pp. 261-271. ISBN 978-963-503-504-5

[5] Hrotkó Károly, - Márk, Steiner - Mihály, Forrai - György Endre, Tóth - Máté, Vértesy - Ádám, Leelőssy - Levente, Kardos - Magdolna, Diószegi Sütöriné - Lajos, Magyar Mészáros (2014): Investigations on environmental benefeits of urban at Corvinus University of Budapest. Plants in Urban Areas and Landscape, Slovak University of Agriculture in Nitra, Faculty of Horticulture and Landscape Engineering pp. 24-27.

[6] Jószainé Párkányi lldikó (2007): Zöldfelület-gazdálkodás, parkfenntartás. Mezőgazda kiadó, Budapest p. 361

[7] Konkolyné Gyuró É. et al. (2003): Környezettervezés. Mezőgazda Kiadó, Budapest, p. 398.

[8] Leverett, Bob - Don Bertolette (2014): The Measuring Guidelines Working Group p. 86.

[9] Lixin, Chen - Chenming Liu - Lu Zhang - Rui Zou - Zhiqiang Zhang (2017): Variation in Tree Species Ability to Capture and Retain Airborne Fine Particulate Matter (PM2.5). Scientific Reportsvolume 7, Article number: 3206 p. 11.

[10] Radó D. (1999): Bel- és külterületi fasorok EU-módszer szerinti értékelése. A Lélegzet.1999/7-8.

[11] Radó D. (2001): A növényzet szerepe a környezetvédelemben. Budapest kiadó. pp. 9-20.

[12] Schmidt Gábor - Tóth Imre (2006): Kertészeti dendrológia. Mezőgazda Kiadó, Budapest p. 404.

[13] Schnier Mária (2005): A köztünk élő fák. Ismeretterjesztő kiadvány. Levegő Munkacsoport, Budapest p. 60.

[14] Tóth Imre (2012): Lomblevelü díszfák, díszcserjék kézikönyve. Tarkavirág, Budapest p. 798.

[15] Veperdi G. 2008: Faterméstan. Oktatási segédanyag, Sopron. pp. 101-107. 